Ана ВУКМАНОВИТ

ana.vukmanovic@hotmail.com

\title{
ГРАНИЧНА БИЋА УСМЕНЕ ЛИРИКЕ \\ - О прекорачењима просторних \\ Београд

\author{
и егзистенцијалних граница \\ лирских јунакиња и јунака
}

\begin{abstract}
Апстракт: У раду се разматра позиција лирских јунакиња и јунака као граничних бића у граничним животним ситуацијама (превасходно везаним за пролећне и свадбене обреде). Та позиција посматра се наспрам значења фигура Другог и странца. Показује се како се у усменим лирским песмама моделују идентитетске кризе у односу јунака према себи и према другима. Мотивима маскирања јунаци добијају зооморфне одлике или се њихов родни идентитет релативизује. Показује се како се инверзијом званичних поредака, током обредног времена, образује простор слободе који пружа утопијски потенцијал алтернативне стварности. Таква стварност могућа је у ограниченом времену и простору, обележеним, као и сама граничност момака и девојака, оказионалношћу. И природа граничних бића и однос средине према њима одређени су амбивалентношћу. Гранична бића су и опасна и у опасности, па су табуи (забране говора, освртања, откривања лица/идентитета, изолација) усмерени да заштите њих од урока и злих сила, али и средину од моћних лиминалних бића.
\end{abstract}

Кључне речи: усмена лирика, гранично биће, странац, Други, идентитет, маска, табу

Пратећи човеков живот од рођења до смрти, усмена лирика је суштински антропоцентрична. Она пева о људима, њиховим емоцијама и доживљајима света, о њиховој онтолошкој и егзистенцијалној позицији у свету. Те позиције песме прате у свој њиховој динамици и сложености, које се посебно очитују у преломним животним тренуцима, граничним ситуацијама (рођење, иницијацијски прелази, свадба, животне кризе, смрт) ка којима је лирика доминантно усмерена. Зато се јунакиње и јунаци лирских песама могу посматрати као гранична бића или бића на граници.

Граничност човека одређује се наспрам њега самог кад долази до егзистенцијалне кризе, кад се мења његов идентитет или се човек удваја у фигури двојника. ${ }^{1} \mathrm{C}$ друге стране, кад се одређује наспрам других људи, гранично биће постаје Други или задобија неке одлике странца. Ако се узме у обзир да страно није исто што и друго,

1 Егзистенцијална маргиналност везана је и за сиромаштво, али је она другачије врсте пошто је сиромаштво трајније стање. О ликовима сиромашних (и сиротих) у лирици видети: Петровић 2014: 197-206, 294-313. 
јер није само различито већ подразумева властиту област и властито бивствовање (Valdenfels 2010: 23), лирски јунаци и јунакиње у поменутим тренуцима прелома, или кризе, превасходно припадају категорији Другог - они имају властито бивство које се понекад и драматично мења (пре свега у иницијацијским моментима), али је њихова област постојања неодвојива од средине где живе и где се о њима пева. Кад, пак, песме певају о свадбеним прелазима, који могу бити прелази из једног простора у други (село, далека земља), девојке и момци доживљавају се као страни. Осећање страности још је израженије у војничким и печалбарским песмама јер, насупрот свадбеним, нема усмерености ка пријему у нову средину. Тада се истиче позиција странца која произлази из односа према другом (уп: Bilefeld 1998: 131). Испеване из перспективе војника и печалбара (или невесте), лирске песме певају о осећају страности. ${ }^{2}$ Негативан став пема страном (странкињи) заузима се и кад се пева о непријатељству према туђој девојци.

Страно произлази истовремено из разграничења и ограничења (Valdenfels 2005: 23). Долази до разграничења између лирских јунака и окружења (војске, туђе средине у којој човек ради, нове породице) и до ограничења његових могућности (нпр. позиција младе снахе у новој кући).

Страност има и свој просторни аспект јер странац стиже преко границе (Bilefeld 1998: 16). У усменој лирици те границе, представљене местима-знацима - гором, водом, пољем, кућом - померају се у динамици кретања из другог села, из даљине, или током свадбеног пута из младожењине у младину кућу. Лирски јунаци и јунакиње страни су зато што долазе из другог простора, али и зато што се око њих конструише представа страног, односно - туђег. Такви су момци и девојке у љубавним и свадбеним песмама, учесници обредних поворки, гости, војници и печалбари, сиромашни. Крећући се, они су симболи повредљивости и спољашњих и унутрашњих граница (Bilefeld 1998: 123). Те прекорачене међе моделују различита идентитетска прекорачења - промене у људима током обреда или током кризних животних ситуација. Зато се може рећи да су границе које се прелазе истовремено просторне и егзистенцијалне.

\footnotetext{
2 Кад момак куне град где је служио, спајају се страност туђине и искуство страности, моделовано мотивом преваре. На вест о томе да Београд гори, момак одговара: „Нека гори, огњем изгорео! / У њему сам три лета служио: / једно лето за светло оружје, / друго лето за добра коњица, / треће лето за лепу девојку; / кад оружје сташе дијелити, / мен' дадоше старо зарђало; / када коње стадоше дијелити, / мен' дадоше старо изјахано; / кад дјевојке стадоше дијелити, / мен' дадоше старо обљубљено“ (Караџић 1975: 595º. Печалбарска ситуација страности моделована је развијеним просторним кодом кад се место боравка приказује као дивље, отворено: „Рано съм цвеке сеяло, / по-рано слана паднало, / та ми цвекето ослани. / Не ми е жално за цвеке, / нел ми е жално за либе, / че е далеко бегало, / оданак Дунав у Влашко, / да коси сено зелено. / Зелен му откос постилкя, / ведро му небе завивка, / мермер му камик узгляве“ (Беновска-Събкова 2005: $297^{\circ}$ ). Тиме се момково преноћиште супротставља домаћем, затвореном свету куће.
} 
Сложену позицију страног заузима невеста која, кад започне свадбени прелаз, не припада више својој породици, али још увек не припада ни младожењиној. У том смислу, њена позиција је лиминална. На овакво егзистенцијално стање упућује загонетка: „Није моја него твоја, није твоја него моја, није ни твоја ни моја него сина

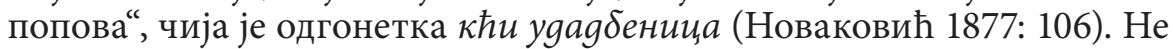
припадајући ниједној породици, девојка припада момку, с којим је успоставила везу у предсвадбеном периоду. О томе певају и лирске песме о спасавању девојке из воде. Супротстављају се искази девојчиних оца, мајке и брата, који одбијају да је спасу: „Тони, тони, ђаволе, / ниси моја ни била!“ (Караџић 1975: 29203) и момка који, улазећи у воду, говори: „Оди к мени душице, / ти си моја и била.“Негирање да је девојка икада припадала својој породици упућује на женску граничност у патријархалној породици, а момково присвајање девојке најављује свадбени прелаз.

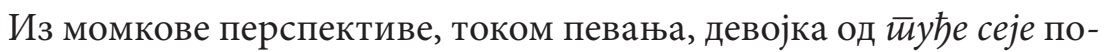
стаје моја љубба. Тражећи опроштај од своје мајке јер: „Ја ћу да идем у туђе село, у туђе село, за туђу сеју, / за туђу сеју, за моју љубу“ (Караџић 1975: $27^{\circ}$ ), он песмом моделује границу свог и туђег света - села, при чему се будућа невеста приказује као гранично биће. У патријархалном моделу њен индентитет одређен је припадношћу породици, мушкарцима, па се на тај начин и мења: одвајајући се од брата, постаје жена.

Разматрајући природу страног, Бернхард Валденфелс примећује да је оно оказионално (2010: 17), а Улрих Билефелд упућује на то да страност није егзистенцијално стање већ стање условљено контекстом (1998: 116). У усменој лирици позиција бића на граници јесте оказионална, али је такође и егзистенцијална - најчешће одређена местом људи у обредима прелаза и преломним животним ситуацијама. ${ }^{4}$ Током светог времена, они постају онострана бића, или бића на граници светова, а по завршетку ритуала, враћају се измењени у људски поредак. Наспрам темпоралне границе формира се двоструки идентитет учесника обредних поворки (и младенаца на свадби). Они су привремено страни (туђи) заједници којој у профаном времену припадају, али и самим себи јер доживљавају егзистенцијалну промену, обредни прелаз. Стога они нису једнозначни, већ су и фикција и конкретност (уп: Bilefeld 1998: 15). С друге стране, војници и печалбари страни су на исти начин као данашњи странци. ${ }^{5}$

3 Ради прецизнијег цитирања, када су песме у збиркама нумерисане, уместо броја стране наводи се број песме, што се обележава симболом кружића иза броја.

4 Карл Јасперс сматра да човек, спознајући граничне ситуације, мењајући своју свест о бићу изнова постаје собом самим (1973: 136). На сличан начин, може се се рећи да девојке и младићи, током кризних ситуација у обредима прелаза, мењају своју свест о себи и добијају нови идентитет.

5 Оно што традицијску културу разликује од савремене, о којој пишу Валденфелс и Билефелд, јесте чињеница да се гранична бића после обреда враћају у свакодневни 
Услед специфичног социјалног положаја, кад не припадају до краја ниједној друштвеној групи (ни деци ни одраслима, ни венчанима ни невенчанима), идентитет лирских јунакиња и јунака јесте нестабилан и може се рећи да они носе границу у себи. Својим кретањем и поступцима је померају, а истовремено те радње и тај простор потврђују њихову маргиналност. У том смислу, они су антропоморфна граница. Попут свих бића, телесно су ограничени, али је истовремено и цело њихово тело међа. Та међа постаје космичка кад је отворено, недовршено тело смеховне традицијске линије повезано са читавим светом (Bahtin 1989: 297). Такву космичко-телесну ситуацију приказује мотив велике невесте: „Мене мому испросише, / клофтер дугу и широку, / баш девојку нинарицу, / не може јој појас бити, / него уже са вршаја, / не може јој прстен бити, / него гужва орачица, / не може јој чорапе бити, / него старе врећетине, / не може јој ципел бити, / него старе козулине“ (Караџић 1974: 355) (Карановић и Јокић 2009: 8). Уз свест о смеховној функцији оваквих стихова, може се размишљати и о томе да отворено тело одговара отвореном идентитету невесте која „није ни твоја ни моја“. Као што је њена позиција лиминална, недовршена, такво је и њено тело. Кад прелази своје границе, она престаје да буде то што јесте (уп: Bahtin 1989: 335) - девојка, и спрема се да постане нешто ново - жена.

С друге стране, одређивање сопствених граница врши се у односу према Другом (Lič 1983: 93-94), као и постављањем, прекорачењем и поновним успостављањем граница - простроних и идентитетских. Током обреда прелаза, учесници се кроз метаморфозе, преоблачења, узимања туђег обличја, општења с другим светом, с туђим, мењају, прелазе међе и, на крају, задобијају нов идентитет. У лазаричким и краљичким песмама те границе се преиспитују маскирањем, преиспитивањем родног идентитета, успостављањем женске обредне групе и у сусретима девојака са сеоским момцима. У свадби млада и младожења изграђују свој идентитет постављајући се једно према другом и према двема породицама. Лирске песме певају о типизираним ситуацијама, али сваким новим извођењем, те ситуације се конкретизују, песме се упућују одређеним људима и реферирају на одређене људе. Тако ће свадбене песме у релативно постојаном тексту замењивати само имена младенаца, зависно од тога на чијој се свадби певају (Караџић 1975: 50, 4º).

Паралела између страног и граничног бића може се повући и у односу на њихово место у поретку. Као што је страно облик изванредног, искљученог из једног одређеног поретка (Valdenfels 2010: 12), као што је истовремено унутар и изван поретка (Valdenfels 2010:

поредак. Паралеле између два умногоме различита друштвена система овде се успостављају на нивоу механизама формирања страности/другости, као и на нивоу природе страног/Другог. Притом се не изједначавају начини функционисања друштвеног система према страном/Другом. 
32), тако се и лиминална бића током обреда прелаза приказују и понашају као и живи и мртви, створења културе и природе, људи и животиње, андрогини (Тарнер 1986: 41). Сходно томе, и странци и гранична бића у усменој лирици могу бити симболи повредивости спољашњих и унутрашњег граница које су само наизглед јасне и стабилне (Bilefeld 1998: 123).

Сложеност феномена страног очитује се и у различитим степенима страности - она је истовремено застрашујућа, претећа и заводљива (Valdenfels 2005: 170). Оваква амбивалентност једна је од основних одлика лирских јунакиња и јунака. Зависно од перспективе и тренутка певања, туђа девојка може бити жељена и радо ишчекивана, али и нежељена и опасна. Често усмене лирске песме заузимају позитивни на однос према страној, туђој девојци (или према туђем момку). Иако је као дошљакиња другачија, чудновата (уп: Valdenfels 2005: 22), стигла преко границе „из Загоре, преко Дунава“" (Беновска-Събкова 2005: 203), омилила је момку који пева песму (или о коме се пева).

У најрадикалнијем виду друго или гранично јавља се као нељудско. Лирске песме нељудско моделују животињским атрибутима, тако јунаци (и учесници обреда) привремено задобијају гранични идентитет између људског и животињског. ${ }^{6}$ Током свадбе онима који се означавају као туђи, други приписује се вучја симболика: вукови могу бити сватови или похођани (Гура 1997: 126), младожења се ословљава с „горјанине вуче“ кад се младенци сведу у ложницу (Херцеговна, Лома 2002: 90), вукови се зову и сватови који праве буку пред ложницом (Босна, Radenković 2000: 28). Кад маскирани момци, као полуљуди-полуживотиње, означавају ратничку дружину (Лома 1998: 208), њихова лиминалност се осим зооморфним кодом наглашава и социјалним будући да они као војничка дружина заузимају маргиналну друштвену позицију. Њихова другост аналогна је „другом“ времену обреда током кога се успоставља антиструкутра (Turner 2008: x), руше се успостављене границе поретка, а привремени поредак је неструктуриран или рудиментарно структуриран и релативно неиздифернциран (Turner 2008: 96), а они сами формирају привремену друштвену групу, чије је изокренуто понашање омогућено скривеним идентитетом (Gunnell 2007: 32-33).

Лирика маску ${ }^{7}$ трансформише у мотив вучје капе: „Ој Бога ми, млад јуначе! / Не проси ме, не даду ме; / не отимљи, погинућеш: / У мен има девет браће, / и толико братучеда, / кад појашу вране коње, / а припашу бритке сабље, / пак накриве вучи-капе, / страота

6 Атрибути нељудског могу се приписати учесницима обреда који ритуално гараве лица. Лице гарави момак кога изводе пред сватове као лажну невесту (Опачић Ћаница 1983: 11), или пустосвати (Попов 1969/70: 53). Осим чађи, онострану природу лиминалних бића открива и блато укаљаних чаројица (Чајкановић 1994: 146-150, 261-292). 7 О зооморфним маскама видети: Марјановић 2008: 251-259. 
је погледати, / а камоли дочекати“ (Караџић 1975: 505º. Зооморфни, гранични индентитет носе чланови мушке групе невестине породице. Они представљају женску варијанту ратничке дружине означене сватовима. ${ }^{8}$ У овом случају момак који покушава да освоји девојку стиже из људског света. Долази до просторне инверзије: свој (девојчин) свет је оностран/нељудски, а туђ (момков) - људски. Браћа сестру чувају од опасности из овостраности.

Вучју капу може заменити самур капа: „Отуд иде турско момче из турске земље, / под њиме је вранац коњиц рода вилина, / а на коњу бојно седло рога јелена, / а за седлом мала узда зуба змијина; / а на њему дуг долама, дуга до земље, / а о пасу танка сабља су три гајтана, / на гајтану три камена, сва три драгана, / на главу му самур капа од веље свиле, / а за капом паун перо пало на раме, / те му лице заклањаше од жарка сунца“ (Караџић 1898: 67º). Момак који гледа девојке у колу граничан је на више начина - као будући младожења, странац (Турчин) и биће повишених моћи атрибуирано спремом са зооморфним елементима (самур капа) и чудесним коњем (вилиног рода, с изузетном опремом - седлом од јеленовог рога и уздом од змијиних зуба). Његова лиминалност је хтонске природе, на коју упућују и заклањање од сунца, које га угрожава. ${ }^{9}$ Зооморфни атрибути дају момку снагу, храброст и брзину (Chausidis1994: 8), а контакт са соларним светом чини га рањивим, чиме се гранично биће показује као моћно и угрожено. Његова амбивалентност потврђује се и у односу девојака према њему, оне одбијају прошевину: „Не просе се ђевојчице у ово коло“, али остављају отворену могућност будуће свадбе: „Но се просе ђевојчице у свога баба““

Зооморфне атрибуте има и девојка-лазарица: „На нашега Лазара / од кондура кошуља, / и од миша опанце, / од лисицу јелека, / и од змију ђердана“ (Бован 1996: 89²). Док веза с вуковима, осим као граничне, момке одређује као снажне и моћне, девојка у опанцима од миша, јелеком од лисице и са ђерданом од змије превасходно је нељудска. Пошто змија носи двоструку симболику - мушку и женску (Гура 1997: 279-280), лиминалност турског момка са змијском

8 Паралела између сватова и вукова постоји и у народној игри „вука“, кад се момци држе за појасеве, трче, вичу: „Вук, вук, вукобача“ и јуре новог момка који се хвата у низу до последњег (Ђорђевић 1907: 107). Вучју маску у епици носи јунаков противник. Он је покривен вучјом или медвеђом кожом и представља звер (Лома 1998: 210). Савлађујући га, јунак доказује снагу и моћ над натприродним противником.

9 Осим односом према Сунцу, хтоничност момка маркира се и змијском атрибуцијом, будући да је змија хтонска животиња (Гура 1997: 282-288).

10 Куна капа такође је зооморфни знак граничног бића, које може бити везано и за ђурђевданске обреде: „Ovo se klanja zeleni Juraj, / zeleni Juraj, zeleno drvce, / zeleno drvce, zelene halje, / zelene halje, ju kuna kape, / ju kuna kape, ju bričke sablje“ (Žganec 195: 44). Зооморфне атрибуте у овом случају има Зелени Јурај као божанство вегетације које доноси плодност. Други део песме чува свадбени контекст и најављује венчање девојке Маре и момка Јуре. Витомир Белај ову свадбу тумачи као хијерогамијски инцест (Belaj 1998: 186-187), чиме лиминалност добија митолошки аспект. 
уздом и Лазара са змијским ђерданом може се посматрати и као андрогина.

Бића на граници, осим нестабилне позиције наспрам опозиције људско/нељудско, одликује и нестабилан родни идентитет, што се исказује ритуалном трансвестијом. У оба случаја реч је о потреби да се прође кроз искуство Другог да би се формирао нови идентитет (уп: Мајерхоф 1986: 21). Усмена лирика на различите начине модепује трансвестију и, зависно од места у свету усмене песме, преоблачење има различите функције.

Лазаричке песме певају о потпуном преоблачењу девојке у момка: „Играј, играј наш Лазаре, / наш Лазаре барјактаре. / Играј, играј наиграј се, / наиграј се, нарипај се, / наноси се мушко руво, / мушко руво белу тоску, / белу тоску алев ћемер, / алев ћемер ал дузлуци“ (Веселиновић 1890: 71). Кад се истиче само један мушки атрибут, онда је то оружје: „Радост, радост, Лазаре, / војска ти се сабира, / и највише надбира, / врани коњи доводе, / танке пушке доносе, / оштре сабље низ куку, / и на сабљу марамче“ (Николић 1926: 56, III). Оружје је део и ритуалне спреме краљица: „Оj, kralıeva majko, / iziđi prid kralı! / Kral se umorio, / perja polomio, / vazdan igrajući, / sablım zveckajući“ (Lovretić: 1897: 411). С обзиром на везу лазарица и краљица са свадбом (уп: Карановић 1996: 280), ритуална трансвестија у овим случајевима могла би се тумачити митом о андрогину, при чему би ритуална симболизација андрогина трансвестизмом била у функцији иницијације (Čale Feldman 2001: 202-203), јер код граничних бића нестабилног идентитета слаби полна поларизација (Turner 2008: 104), а полност се стиче током обреда, кроз искуство митске целовитости (Čale Feldman 2001: 203).

Међутим, током свог лиминалног статуса, девојке шире дијапазон женске представљачке слободе с циљем присвајања неспутаности понашања и друштвене моћи (Čale Feldman 2001: 205). ${ }^{11} \mathrm{O}$ том слоју усмене лирике који упућује на женску супкултуру (уп: Antonijević 2013: 19-20) сведочи и мотив девојке која се огледа у води и такође је опасана сабљом: „Приморкиња коња јаше, /ко делија сабљу паше, / над воду се надносаше, / сама себи говораше: / Мили Боже, љепа ли сам! / Танка ти сам и висока! / Б’јела ти сам и румена! / Још да су ми црне очи, све би старо помладила, / све би младо помамила, / и жењено раженила, / нежењено оженила. / Све би оџе разоџила, / а попове распопил““ (Петрановић 1989: $\left.174^{\circ}\right)$. Овим стиховима исказује се моћ девојке над младим и старим мушкарцима. Њена моћ лежи у изузетној лепоти, али се секундарно представља и мотивом сабље. Може се рећи да се граничност девојке моделује

11 Ритуална лиминалност формира хронотоп повлачења уобичајених модела друштвеног деловања, али такође може носити потенцијал испитивања доминантних вредности друштва (Turner 2007: 167, 184). О том потенцијалу као утопијском говори и Бахтин (уп: Bahtin 1978: 104). 
наспрам ње саме мотивом огледања/удвајања и наспрам другог/ мушког присвајањем јуначког атрибута.

Маскирањем у лирици девојке освајају мушки друштвени простор: „Ево данас година девета / како дворим Ченгић Али-пашу / нитко не зна јере сам дјевојка / а данаске с[а]крити не могу: / расту дојци, црвен атлас пуца, / срце иште, љубити се хоће, / око ме се тканица распела, / пустиле се мукадему ресе, / кошуља се бјели под кафтаном, / шарене се гаће под кошуљом, / а бијеле се ноге под гаћама, / а на ноге жуте се пашмази“ (Геземан 1925: 68²). Девојка не жели да борави у мушкој сфери, напротив, осећа полно сазревање и буђење еротске жеље. ${ }^{12}$ Скривање идентитета и бујање лепоте средства су моделовања граничне животне фазе. Песма разрешава лиминалну кризу повратком у сферу женског и поновним успостављањем женског идентитета. Упркос томе што је девојка девет година непримећено живела као „Мујо“, кад јој донесу ђерђеф и преслицу: „Љепше преде челебија Мујо, / љепше преде него пашиница; / љепше везе челебија Мујо, / љепше везе него пашиница“.

Жељено или не, прерушена девојка врло успешно обавља мушки задатак бацања камена да би доказала свој „мушки“ идентитет. Дан војвода треба да иде да кумује у девет села и да крштава у десетом. Жели да поведе са собом сестру, али се боји да је не види и не узме црни Арапин. Она га саветује: „Премени ма с мажки дреи, / па тури ми самур калпак / и я с тебе да отида!“ (Арнаудов и Вакарелски 2004: $104^{\circ}$ ). Када Арапин посумња да је ипак реч о девојци, тражи да се подвргне провери: „Не е това арен юнак, / ами е това малка мома! / Айде да идем на пазара, / ако баде арен юнак, / той ще узе меден кавал; / ако ли е малка мома, / тия ще узе танка хурка! / Па отишле на пазара, / а тия узе меден кавал, / та засвири, та запея, / надсвирила всички момци. / Черно вагре отговара: / - Не е това арен юнак, / ами е това малка мома! / Да идеме, да видиме, / дек са мета бели камик, / ако надметне всички момци, / тогава е арен юнак! / Отишла е малка мома, / дек са мета бели камик, / узела е бели камик, / надметнала сички момци.“ Попут јунакиња епских песама које су заточнице очева или браће, јунакиња лирске песме има сложен идентитет, који није само прикривен самур-капом, већ подразумева мудрост да издржи искушење (да изабере кавал), спретност (да у кавал свира),

12 И девојка која живи као јунак плаче над таквом судбином: „Ево има девет годиница / нико не зна да сам женска глава, / веће једна Анђелија праља, / која ј' мени б'јело рухо прала, / рухо прала и косе чешљала“ (Рајковић 1869: 246º). Песма такође пева о женском пријатељству. Сложена идентитетска позиција тишти девојку, а заједничка тајна успоставља посебну блискост између јунакиње и праље. Такво женско разумевање одговара лирском песништву као женском, понекад затвореном у женске групе (обредне или необредне). Изузетна блискост међу девојкама моделује се и мотивом умивања другарица на једној води: „Dvi su druge virno drugovale, / na jednoj se vodi umivale“ (Andrić 1929: 258²). Виктор Тарнер примећује да се међу неофитима развијају снажна пријатељства обележена односима једнакости (2008: 95), који се могу пронаћи и у лирским сликама пријатељства. 
снагу и окретност (да баци камен даље од момака). Оваквом сликом девојке показује се лирска осетљивост према питањима идентитета и отовореност ка сложеним родним концептима. Тако се сестра Дан војводе приказује као гранично биће, јер је неудата, и јер је способна да савлада „мушке“ задатке постављене пред њу у тренуцима кризе.

Гранична ситуација може бити везана и за еротско искуство. Двоструки идентитет има девојка која је дању барјактар, а ноћу љуба: „К'д Али бег нови бег бијаше, / девојка му барјака носаше./ Дању носи пред бегом барјака, / а у вече с бегом у душеке“ (Ястребов 1886: 194). Родна граничност не успоставља се маском већ друштвеном улогом. Девојка барјактар улази у мушку (војничку) зону. Њен идентитет није прикривен, па агина дружина прети аги да ће га напустити ако се не одрекне девојке, што он не чини. ${ }^{13}$ Ага је лирски јунак, који се својим избором моделује као граничан - претпостављајући девојку дружини, а љубав обавези, он оспорава патријархални поредак и изокреће јуначке вредности. Девојка присваја јуначку улогу заправо је негирајући у борби у којој побеђује женски принцип. Лирска песма овом приликом пружа пример културе оспоравања (Nenola 1999: 23), која формира представу могуће, алтернативне стварности. ${ }^{14}$

Привидна трансвестија део је еротске игре скривања, која се открива у разговору мајке и ћерке: „Ко ј’ то, Јело, с тобом код оваца? / Ово j’, мајко јараница моја. / Кад је, Јело, твоја јараница, / окле њојзи зелена долама! / Није ово зелена долама, / но је ово зелена ливада. / [...] Окле њојзи нож и пушка мала? / Није ово нож и пушка мала, / но је ово дуга и преслица. / [...] Окле њојзи капа и челенка? / Није ово капа и челенка, / но је ово ђердан од дуката“ (Радојевић 1892: $\left.265,7^{\circ}\right)$. Момак није прерушен у другарицу, већ се девојчина обмана формира око игре идентитета - замене мушких атрибута женским (нож и пушка - дуга и преслица, капа и челенка - ђердан), а еротски сусрет на момковој долами приказује се као слика девојака на ливади. Маскирање у девојку (иако нереализовано већ присутно само у ћеркином оправдању) омогућава момку да општи с драгом. ${ }^{15}$ Овим поступком лирска песма моделује момка и девојку као бића

13 Насупрот томе, девојка барјактар током свадбе не изазива зазор, већ води девојке на реку да играју и певају (Мокрањац 1966: $24^{\circ}$ ), што се може тумачити као руковођење једним делом обреда.

$14 \mathrm{O}$ моћним женама и девојкама пева се и унутар пародије епског обрасца кад удовица, као посебно маргинализована жена, инверзно постаје моћна, пародично добијајући јуначку титулу: „Бојало се момче дјевојка, / и на брду кућу начинило, / од челика врата саковало, / ударило челикли мандале. / Помоли се чета дјевојака, / пред њима је сердар удовица, / како дође помама је нађе: / удри ногом о челикли врата, / разбише се на двоје на троје, / уфатише оно момче младо“(Караџић 1898: 580). Девојке и удовица као њихов вођа формирају девојачку дружину, предузимају јуначку акцију - отмицу, при чему за себе освајају простор слободе и могућност да бирају момка. 15 Мирјана Детелић показује да у епици маскирани добија моћ онога чије обличје носи, право да општи с њим или да се против њега бори (1992: 238). Љубавни сусрет под маском у лирици моделован је аналогно епској борби. 
на (предсвадбеној) граници, а том лиминалном периоду одговара и слобода понашања, чиме лирика на још један начин формира слике утопијске стварности.

Овакве песме показују осетљивост лирике (и лирско-епских песама) према питањима Другог. У одређеним (лиминалним) ситуацијама, родне разлике се не приказују као противречности већ као комплементарности, одлике које могу постојати напоредо у једном бићу.

Сходно томе, не може се рећи да усмена лирика моделује женско као апсолутно друго (уп: Levinas 1997: 67-68) јер за женске йесме друго једнако може бити и мушко. Будући да свадбене песме имају свој мушки и женски текст, у женском тексту, апсолутни Други постаје младожења као биће које долази преко границе, потенцијално из оностраности. Позиција момка као Другог наглашена је кад је он сужањ кога доводе преко мора. Кад девојка пита: „О старице, мила моја мајко, / што се оно у мору бијели? / Ил су ловци или су трговци? / Али моја браћа од Оциња?“ (Караџић 1898: 361), мајка одговара да морем долазе њена браћа и довозе сужње, а девојка тражи да их дају њој, да их баци у тамницу и мори глађу и жеђу, али затим долази до преокрета: „Не меће их у дно од тамнице, / но меће их у бијеле дворе, / те им дава пива и јестива“. Момци које девојка узима за себе онострани су јер долазе с друге обале, али и зато што су странци. Будући удвојеног лика, они нису младожење већ су поклон девојци. Сужањство се трансформише у еротски мотив романсе.

Као што се страно одређује као спољашње наспрам унутрашњег, туђе наспрам властитог, оно које је другачије врсте, чудновато, неодомаћено, ретко, супротно познатом (Valdenfels 2010: 120), тако и лирска гранична бића привремено не припадају унутрашњем поретку заједнице (лазарице, на пример, долазе преко воде из оностраног - Ястребов 1886: 110) и одређују се као туђа (могуће онострана - уп: Љубинковић 2014: 378).

Такву неприпадност бића на граници краљичка песма моделује мотивом непрепознатљивости неудате девојке: „Ovde nama kažu / seku neudatu, / seku nepoznatu“ (Kuhač 1941: 272º). Не само да је девојка (привидно) непозната за краљице, већ током обреда учеснике ритуалних поворки житељи насеобине не препознају као синове, ни кћери (Љубинковић 2014: 378). Њихова привремена искљученост из властите средине, по завршетку обреда, завршава се поновним укључивањем и прихватањем (уп: Bilefeld 1998: 13). ${ }^{16}$

Однос према Другом, страном у лирским песмама је амбивалентан (уп: Valdenfels 2005: 50). Пример таквог односа пружа поређење значења готске речи gastis и старословенске gost ̌ у значењу „гост“ с латинским hostis - „непријатељ“. Закључује се да је странац и гост

16 С друге стране, позиција војника и печалбара није везана за обред и не подразумева укључивање. Они остају страни средини у којој бораве, а у поредак се имплицитно враћају повратком кући. 
и непријатељ (Бенвенист 2002: 58). То што је hostis равноправан с римским грађанима у основи је установе гостопримства (Бенвенист 2002: 60). ${ }^{17}$ И сам гост је биће на граници. Он је транзиторна фигура - није ни код куће, код себе самог, није ни само на путу, изван себе самог (Valdenfels 2005: 49). За лирске песме, гост је привлачан, моделује се као драги момак, кога домаћинове сестре прате: „Све три су ме испратиле: / Миличица до капије, / Љубичица до ћуприје, / Де-Неранџа у планину“ (Карановић 1990: 80). Улазећи у нељудски простор планине, девојка исказује спремност да се одвоји од своје породице и крене у дрги свет, нови живот с момком. Варијантно, најављује се коитус између девојке из куће и госта: „Кад пођемо у ложницу, / Ружичица душек старе, / Љубичица јорган старе, / Гонџе Ана са мном легне“" (Караџић 1898:515²). Љубавни мотив може се повезати с веровањем да је гост потенцијално отеловљење божанства, па га се укућани и боје и настоје да његову моћ задрже у кући тако што ће му дати да ноћи с домаћом девојком (Чајкановић 1994: 149).

Амбивалентност односа изражена је према млади као туђој, страној, током свадбе. Њу хвале, али према њој исказују и непријатељство. Похвале и покуде заправо су део двотелесне слике (Bahtin 1989: 449-451), два лица исте обредне појаве. Обред ствара могућност да се користе неуобичајене језичке форме, које се у свакодневним ситуацијама не употребљавају (Карановић и Јокић 2009: 6). Невеста се приказује као неука: „Бумбул пјева у ружици: Саба зора је! / устај горе, нево наша, кити дарове - / Ја сам луда и нејака, ја не умијем“ (Караџић 1898: 9²). Будући да је перспектива женска, изговор неукости носи потенцијал побуне против идеалне слике вредне и послушне девојке. Тиме што не жели да устане и спреми дарове, она се симболички опире удаји. Искази могу бити ближи обредним увредама: „Узели сте, ал' нисте пробрали. / Узели сте прељу - неткаљу, / Узели сте ткаљу - непраљу, / Узели сте праљу - нешваљу, / Узели сте шваљу - непрељу, / узели сте нерадну девојку“ (Ђорђевић 1907: 185). Покуде могу бити средство магијског зауздавања женских моћи кад их исказује младожењина породица (уп: Карановић 2010: 152), или средство заштите од урока којима је изложено посебно вредно (а гранично) биће. Заштита је двоструко усмерена - ка невести и од ње (ка новој породици).

Стиховима: „Tri se leta počesala nisi, / četiri se umivala nisi. / Kad se jesi počela česati, / tri tovara češlja potrgala; / kad se jesi počela umivat, / celu Kupu vode zamutila, / ni na pol se umivala nisi!“" (Žganec 1950: $300^{\circ}$ ) непријатељство се моделује опозицијом људско: нељудско, јер будући неочешљана и неумивена, невеста се показује као нељудска. Нечистоћа одговра поменутом мазању чађу са значењем невидљи-

17 Да туђина не значи нужно непријатељство показују и грчка именице agrós - „поље“ и придев ágrios - „дивљи“ (Бенвенист 2002: 210), с потенцијално различитим конотативним значењем - странац је онај који долази споља, ко је изван границе заједнице (Бенвенист 2002: 237), или онај ко је дивљи. 
вог и оностраног. На овај начин се гранични статус девојке маркира двоструко - она је Друга и као снаха и као нечиста/онострана.

Иако су увреде девојци чешће, обредно се вређа и младожења: „Мили Боже, чуда големога! / Где дадосмо злато за олово! / Сребро сјајно, а олово тавно“ (Караџић 1975: 62º. Будући да песма заузима женску перспективу, унижавањем младожење уздиже се невеста, а не пружа се ритуална заштита. Сходно женском тексту свадбе, поставка опозиције светло/тамно изокреће се у односу на патријархални модел, па светлом одговара женско, а тамном мушко.

Као учесници обреда и сватови су привремено гранична бића, чије се моћи зауздавају ритуалним непријатељством. Њихово заустављање („Натрак, натрак кићени сватови! / Туђа земља, туђа је девојка. / Не сте харач овде ви давали. / Ову земљу не сте ви купили - Ястребов 1886: 401), одбијање сватова („У нас је мома још непрошена. / Ми ћемо доћи да је просимо. / Ви ћете доћи, ми је не дамо. / Богме ћеш дати, и наша бити“ - Караџић 1975: $1^{\circ}$ ), задржавање при уласку у невестину кућу, захтев да прво покажу своје намере, представљају обредно непријатељство према туђој групи, дистанцирање од ње. Међутим, пошто затим долази до пријема, обредне радње се остварују као етапе зближавања страних и локалних (уп: Van Genep 2005: 34), ${ }^{18}$ чиме се изнова релативизује однос према туђем.

Амбивалентност граничне позиције испољава се и кроз статус бића на граници. Она су истовремено у опасности јер су изван друштва и опасна по друге јер их сакрална сфера чини јаким (Ван Генеп 2005: 31-32).

У свадби се угроженост ублажава благословима. Да би прешли у наредну фазу живота, младенцима је неопходан опрост. Зато девојка моли: „Лепо се Милка роду молила, / ој роде, роде, мој мили роде, / пустај ме роде из твога двора, / из твога двора, са златног стола“

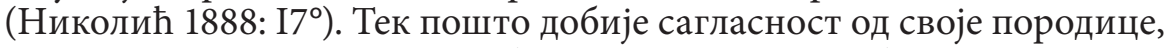
девојка може да крене преко (просторне и статусне) границе ка новој кући. Опроштај се добија из центра породичног култа (Топорков 2012: 167-168) - добивши дозволу да оде из двора, од стола, она креће на пут у други свет. Осим у центру домаћег култа, девојка опрост добија и на води као такође култном месту, али на просторној периферији свог света: „Па се шњима пошетује / до хладенца хладне воде, / ту наоди младу Васу, / благослов јој мајка даје: / пођи с Богом, ћери моја, / Бог ти дао свако добро“ (Караџић 1898: 32). Благосиљајући кћер на води као станишту демона и душа предака (уп: Mencej 1997: 13-24), мајка невести преноси и благослов мртвих. ${ }^{19}$

18 Магијско вређање сватова моделују и басме. Сватови се по принципу бројности повезују с крастама (Раденковић 1982: 153), или се описују као криви, неми, глуви, ћорави (Раденковић 1982: $165^{\circ}$ ). Такве паралеле су могуће јер је традицијској култури познато обредно унижавање учесника свадбе.

19 Мајчин благослов је важан зато што, осим обредног прелаза, мајчин благослов је важан и зато што омогућава ћерки да у нови дом понесе моћ рађања (Карановић 1993: 22). 
Двострука природа граничног бића нарочито обележава невесту. Опасна девојка може бити гневна: „Не стој, куме, не стој стари свате, / не гњев'те нам гиздаве девојке, / девојка је и од себе гњевна, / остаје јој рукав недовезен“ (Караџић 1975: 50 ${ }^{\circ} .{ }^{20}$ Бес граничног бића може бити кобан по све који се налазе око њега, посебно по поредак породице у коју ступа. С друге стране, недовезен рукав угрожава невесту или младожењу: недовршен магијски рад не обезбеђује заштиту веза као посебног апотропајона - на невестиној спреми или дару за младожењу. Младина моћ није нужно опасна, већ може бити и плодоносна: „Воде Јању од Соколовића; / прео које горе преведоше, / она гора јабуком родила; / прео које воде преведоше, / она вода вином отјецала; / у које је село уведоше, / оно село здраво и весело; / у коју је кућу уведоше, / око куће сење и јасење, / а у кући здравље и весеље“ (Рајковић 1869: 145º. Моћи потичу од плодности жене и од женске позиције између природе и културе. ${ }^{21}$

И систем табуа познаје представу о моћној жени, одговорној за контролу својих натприродних моћи. Мушкарац је приказан као немоћан и зависан од њених ћуди (Radulović 2009: 162). Као што су табуи повезани с прелазима, неодређеношћу, неправилностима, границама између категорија (Hamilton 2003: 237), такву неодређеност и граничност у себи носе лиминална бића. Самим тим, забрана учествује у давању облика, било као негативна баријера, било као позитивно постављање границе (Kasirer 1985: 88). Њоме се стабилизује систем и уобличава идентитет граничних бића. Лирика пева о табуима који регулишу понашање невесте, какви су прописивање обредног ћутања (или особеног говора), забрана откривања лица, освртања и изласка из куће.

Особени свадбени благослов јесте добра молитва коју родитељи дају кћерки док је брат држи за једну а девер за другу руку -док је на граници обележеној персоналним кодом, двојицом мушкараца. У Паштровићима се она даје за трпезом док девојка клечи на поду држећи оружје, а над главом јој је раширен вео. Добра молитва се казује и на кућном прагу, као и на прагу нове куће, кад је даје свекар (Караџић 1852: 124-125), чиме се везује за центар (трпеза) или за границу свог света (праг). Гранични тренутак прелаза маркирају очеве речи: „Из овога дома ижљегла у добар час! А у други дом уљегла у бољи час!“ О коначности прелаза сведоче следеће очеве речи: „И да ти у ови дом повратак више не буде, већ ако гостом кад дођеш“" (Караџић 1852: 125). О доброј молитви и молитвеној чаши видети: Диздаревић Крњевић 1997: 71-81.

20 Зауздавање љутње је у функцији формирања патријархалног идеала послушне девојке: „Снашице, зрно бисера / и кито свакога цвијећа! / Немој нам бити срдита, / срдита и огњевита, / срдитост тури у воду, / а огњевитост у гору, / него нам буди весела, / весела и послушљива, / покорна и умиљата“" (Караџић 1898: 4). Зауздавањем друштвено неприхватљивих емоција, зауздава се и женска воља.

21 Ако жена може да влада елементарним непогодама и природним силама, онда може да их употреби и против поретка. Тако се, на пример, образује алтернативна представа материнства: „Цвеће сам цвеће / док ја немам деце; / кад узимам деце, / увену ми цвеће“ (Караџић 1975: $412^{\circ}$ ). Док је жена, пролазећи кроз пејзаж, подстицала раст, овде позитивно вреднује девојаштво, а негативно рађање. 
Радост Иванова бележи да је табу говорења могао да траје и четрдесет дана после свадбе (Ivanova 1987: 55), а с престанком забране, снаха излази из периода пасивности (Ivanova 1987: 75). ${ }^{22}$ Ритуална тишина означава позицију између живих и мртвих будући да је глас одлика људског, а његово одсуство нељудског света (Детелић 1992: 58). Опозицијом одсуство/присуство гласа, аналогној опозицији нељудско/људско формира се још једна граница - у говору. Песме забрану говора моделују као савет невести: „Ој ти зрно шенично! / ти не буди језично, / па ћеш бити честито; / ако л’ будеш језично, / нећеш бити честито“ (Караџић 1975: 122º). Поређењем са стиховима о гневној девојци, образује се представа заузданих женских моћи, маркираних снажним емоцијама и говором.

Близак ћутању је и обредни говор. Посебан начин обраћања издваја младу (или учеснике обреда) као маргиналну. Она у новој кући све зове по надимцима (Караџић 1957: 144). Такав пропис може се објаснити чудесном природом младожење и његове породице (као Других - оп. А. В.) из младине перспективе (Левингтон 1982: 97), али и заштитом укућана од придошлице, моћне жене повезане с нечистим силама (Radulović 2009: 162). Позитиван однос према својти постиже се фитонимнском и зоонимнском метафоризацијом: паунови - свекар и свекрва, паунице - заове (Караџић 1975: 113º), акционом: заповест - свекар, саветовање - свекрва, шетња - девер, миловање - заова, брига о детету - јетрва (Караџић 1975: 112º), и социјалном: кнегиња - свекрва, левер - девер, госпођа - јетрва, везиља - заова (Караџић 1975: $\left.180^{\circ}\right)$. Негативан став исказује се клетвом и зооморфним кодом: козја брада - свекар (Караџић 1975: 701º), коњска глава - свекрва (Караџић 1973: 318), и акционим: чичоглава - свекар, ломигора - девер, лупежице - заове, карачице - јетрве (Караџић 1975: 701) (уп: Сикимић 1998: 34-47).

Будући да је млада као гранично биће угрожена, прекривајући се велом, штити се од урокљивих очију (Bandić 1980: 351). Тако вео штити и од опасних додира пошто је и сам поглед врста додира (Ван Генеп 2005. 193). ${ }^{23}$ Посебно се пази да се вео не подигне на путу, у граничним и хтонским просторима: „Када буду кроз гору зелену, / ти подигни росу са јаблана, / да нам коло не дофати грана, / не дофати два млада ђевера, / јел' међ' њима лијепе ђевојке, / да не смакне чембер са ђевојке, / да јој свати не гледају лице“ (Петрановић 1989: $\left.94^{\circ}\right)$. Док су девери као обредни пратиоци такође гранична бића угрожена на путу, невестина граничност је вишег реда - она је започела обредни прелаз (између две породице, две друштвене групе и две животне фазе), али је и изузетно биће стога у опасности од урока. ${ }^{24}$

22 Везу гласа са нељудским просторима потврђују и басме које нечисте силе терају у просторе без гласа (Раденковић 1996: 27).

23 Ношење покрова/вела од прошевине или изласка из родитељске куће могла би бити редукција обичаја покривања девојке од полне зрелости (Зайковские 1999: 114).

24 Мотив угрожене лепоте типичан је за баладе: „Ој пунице, ђевојачка мајко! / Или 
Дивљина маркира оностраност при чему је зелена гора као удаљена од људског света типични хтонски простор (уп: Детелић 1992: 59), а роса метонимија природне стихије..$^{25}$ Осим што упућује на угроженост девојке, покривање лица је, попут табуа говорења, обележава као лиминалну, привремено нељудску - невидљиву (уп: Јокић 2008: 46). ${ }^{26}$ Сходно томе, девојка прикрива лице и зато што својим моћима може да угрози друге, посебно младожењу (Bandić 1980: 351), па покривање означава и ритуалну изолацију оног ко је привремено загађен светошћу, опасан и нечист (Lič 1983: 116).

Песме момкову угроженост моделују као скривање од села и Сунца: „Од села се штитом заклањаше, / а од сунца струком босиока, / да га не би опалило сунце“ (Караџић 1973: 28). Његова граничност је нељудска - супротстављена селу као људском свету и Сунцу као носиоцу соларног принципа.

У предсвадбеном времену истиче се посебна угроженост девојке која није прошла брачну иницијацију и као таква је гранична. Она се зато штити прикривањем идентитета. Облачи снахино рухо како би безбедно отишла на воду и избегла хајдучку заседу или отмицу: „Кад то дочу Сенија девојка, / па обуче снахино одело, / па отиде на воду студену“ (Бушетић 1902: 164). Маскирање представља прекорачење идентитетске границе и, у овом случају, има заштитну функцију. Под маском девојка је неко други - удата жена, и стога мање угрожена у лиминалном простору и у сусрету с еротским набојем (уп: Детелић 1992: 96). ${ }^{27}$

Обичај извођења лажне младе ${ }^{28}$ такође се заснива на скривању идентитета. Заштиту, међутим, не пружа симулирање друштвеног статуса удате жене већ умножавање девојака у невестинској спреми. Усмена лирика овај обичај премоделује као задатак момку да препозна девојку: „Гледай, согледай, юначе, / каква ти мома даваме, /далиетая, юначе, / йелиедруга, юначе!“ (Арнаудов и Вакарелски 2004: $\left.391^{\circ}\right){ }^{29}$

си је од злата салила? / Или си је од сребра сковала? / Или си је од сунца отела? / Или ти је Бог од срца дао / [...] Кад су били гором путујући, / стиже урок на коњу ђевојку“ (Караџић 19886: $78^{\circ}$ ).

25 Опасност од росе отклања соко који припрема сватовима пут кроз гору: крилима уклања иње, а кљуном ситну росу (Николић 1910: 291a). Таква позиција птицу одређује као водича кроз гранични простор и заштитника од стихије.

26 Веза са опозицијом видљиво/невидљиво успоставља се и обредном праксом. Када се вео скида када падне мрак (Пантелић 1968: 124), ноћ преузима функцију скривања младе, па са може рећи да вео постаје излишан.

27 Мотив прикривања идентитета маскирањем развијенији је у епици: „Pa ti ajde u gornje komore, /meći na se dvi svile bijele, /a na ruke devet prstenova, / svaki valja za devet gradova, / a na čelo dva draga kamena, / pri kojima možeš večerati / i još devet konja potkovati / u ponoći kano i u podne, / a na glavu vidro okovano, / pa ti ajde na vode za goru“ (Bosanac 1897: $37^{\circ}, 31-40$ ).

28 О лажној млади, видети: Шневајс 1927: 23.

29 Епске песме и бајке моделују мотив препознавања невесте међу једноликим де- 
Аналогна лажној млади јесте изофункционалност младожење и девера (уп: Сикимић 1999: 340). Момак поручује девојци коју мајка грди због његовог честог долажења: „Сакупићу господу сватове, / све сватове прије нежењене, / вране коње прије неседлане, / бритке сабље прије непасане, / самур-капе прије неметане, / брата мога на моме коњицу, / у мом руху, у ођелу моме, / и мојему свијетелу оружју, / да ме прије ти упознаш душо“ (Караџић 1898: 71). Док су сватови лиминални као нежењени, зооморфни, с имплицитном позицијом невиности (неседлани коњи, некоришћено оружје и неношена одећа), момкова лиминалност моделује се мотивом двојника у лику његовог брата - у њега преобученог. Необична порука да ће га девојка пре упознати сусревши се с његовим братом говори о значају проласка кроз искуство Другог за изграђивање сопственог идентитета: кад момак не иде са сватовима (нпр. Медаковић 1860: 41), прерушени брат мења младожењу, при чему девојка упознаје сложени лик момка: поред оног који као његова драга зна и онај други, гранични, удвојен. Фигура двојника тако истовремено штити јунака у тућем свету (замењујући га) и утиче на формирање идентитета бића на граници. ${ }^{30}$

Момкова удвојеност не везује се само за мотив двојника, већ и за обредно понашање учесника сватовске групе. Младожења се крије под свечаним рухом међу сватовима: „Па кад будеш спрам шурина двора, / спрам шурина и спрам пуничина, / пустај скерлет коњма до колена, /златне узде коњма до очију, / све два и два у двор улазите, / нек се не зна ко је ђувегија“ (Бошковић 1879: III 13º). Сред туђег света, какав је за младожењу невестин дом, он је као граничан угрожен, зато је неопходно да се чува. Док је девојка у краљичком обреду била непозната као онострана, момак је непрепознатљив јер је прикривен његов лични идентитет и он је постао део једнолике групе.

Удвајати се могу сватови, па у девојачку кућу улазе заједно: „Долетеше до два коња врана, / оба врана, оба једнолика, / и на њима до два момка плава, / оба плава оба једнолика“ (Бушетић 1902: 13). Муштулугџије се тако моделују као гранична бића, или удвојено биће, и као учесници обреда разликују се од себе ван ритуалног времена. У сталној покретљивости лирских перспектива, девојка сама тражи да по њу дођу једнолики момци: „Него му иште кола седмора, / кола седмора, коње седмаке, / коње седмаке, момке јед-

војкама. Финкција умножавања није заштитна, већ је оно средство провере јунака (Караџић 1988а: 29을 517-525; Чајкановић 1927: 40).

30 Ређа је у лирици изофункционалност невесте и њене сестре, али се среће кад младожења свастици дарује киту цвећа као невестински знак: „Млади Јанко три ките набрао, / једну киту за шал заденуо, / другом китом коња закитио, / трећу киту свасти даровао“ (Бушетић 1902: 99²). Момкова граничност присутна је у родној инверзији јер он, а не девојка, манипулише биљем, способан да заштити себе (и коња) и да искаже нежност према свастици и успостави везу с њом. 
наке“ (Караџић 1898: $104^{\circ}$ ). ${ }^{31}$ Ово умножавање не штити момке, већ девојку на путу. Такви једнолики јунаци моћна су сила против злих духова јер им скрећу пажњу са младе, а и сами су појединачно нераспознатљиви. Као и у претходном примеру, у граничној позицији формира се ритуална група и слаби њихов индивидуални лик. ${ }^{32}$

Бића на граници, симболички приказани као бића на путу, не смеју се освртати када једном пођу на пут прелаза: „Пођи с Богом, наша неве, не обзири се / на бабове б“јеле дворе“ (Караџић 1975: 60). Да би била примљена у нову кућу, невеста мора прекинути све везе са старим светом. Ако то не учини, угрожава свој будући статус и сигурност нове куће, јер у њу улази неко ко још увек припада туђем свету.

Насупрот томе, лирика пева управо о кршењу забране. Девојка се осврће и то објашњава: „Ој ђевере, мој ђевере, / ја се млада не осврћем / на тајкове б'јеле дворе, / на браћине пеливоје, / на мајчине разговоре, / но ђе сам синоћ коначила, / ту сам млада оставила / в’јенце, ресе и обоце / и прстене позлаћене“ (Караџић 1898: 17º). Девојка крши табу освртања, али се то не санкционише и не означава опасност. Кад се негира усмереност освртања ка старој кући, премоделује се коначно одвајање од претходног живота. Освртање је усмерено ка заборављеним свадбеним симболима. Имплицитно, заборављање може значити губитак, а губитак венца може наговештавати дефлорацију, будући да је он симбол невиности (Гура 1995: 321) - чиме би се спојили различити аспекти лиминалности: просторни (пут), временски (ноћ) и егзистенцијални (губитак невиности). Гранична криза тако се моделује губитком спреме, а не освртањем.

Као што се страно може мислити као место страног, као негде другде, као изван-редно (Valdenfels 2005: 12), тако и бића на граници имају свој локативни аспект. Границе у простору аналогне су бићима на граници. Они, како је показано, могу долазити/одлазити преко међе (стизати преко воде, одлазити у гору). Међутим, посебну граничну ситуацију означава обредна изолација. Она формира место страног као хетеротопију кризе, привилеговано/свето/забрањено место, намењено појединцима који се налазе у кризном стању (Foucault 1997: 3). Као што је хетеротопија фрагментаран простор где се спајају различита и инкомпатибилна места, стварајући простор као илузију (Foucault 1997: 5-6), тако је идентитет граничних бића фрагментаран, нестабилан - лиминалан. Тако она у идентитетском и просторном смислу нису „ни тамо ни овде“ (Turner 2008: 95).

31 Девојачки род се чува од опасних гостију и пребројавањем сватова. Бројање означава раздвајање, успостављање границе између познатог и непознатог (Раденковић 1993: 87): „На ред, на ред, кићени сватови, / све два и два у ред долазите, / [...] све два и два коње одјахујте; / [...] све два и два за совру седајте; / да не позна девојачка мајка; / које вам је млади ђувегија“ (Матицки 1985: $5^{\circ}$ ).

32 Група од седам једнаких момака има посебну снагу у балади и једина успева да преживи кобни пролазак кроз гору (Караџић 19886: $\left.78^{\circ}\right)$. 
Будући опасна и у опасности, издвајају се у просторе изолације да би се околина заштитила од њихове култне нечистоте и магијске снаге и да би се сами заштитили током осетљивог животног периода (уп: Lič 1983: 116).

Лирске песме место изолације приказују на различите начине. То може бити женска (девојчина) кућа, означена породичним односима. Успостављају се динамични односи, па свој унутрашњи, затворени простор, за девојку, постаје туђ за момка: „Дойди, дойди, бела Билке, или кя ти дойда! / И да дойдеш, бел Босилчец, каде кя ме наеш? / Кятенайда, бела Билке, татко идвори! / [...] Кятенайда, бела Билке, в братои одаи! / [...]Кятенайда, бела Билке, у майкини скути!“ (Арнаудов и Вакарелски 2004: $313^{\circ}$ ). Простор изолације се сужава од дворова, преко одаја, до мајчиних скута који обележавају наглашену димензију унутрашњег и безбедног, и носе симболику рађања.

Слично се моделује простор који момак савладава да би стигао до девојке: „Чија ли је тараба, / чија ли су врата, / чије ли је оно луче, / што на пенџер гуче? / Мајкина је тараба, / мајкина су врата, / мајкино је оно луче, / што на пенџер гуче. / Прескочићу тарабу, / прескочићу врата, / пољубићу оно луче, / што на пенџер гуче“ (Караџић 1973: $\left.427^{\circ}\right)$. Сужавање женског простора одговара момковом савладавању препрека. Као и у претходном примеру, перспективе су покретљиве и наспрам њих се релативизује одреднице свој/туђ: оне алтернирају, али се не поклапају. Структура лирске песме прати ту динамику: питањем о припадности простора и девојке они се моделују као непознати, одговором се одричу момку као туђи, а затим долази до савладавања препрека и присвајања девојке. Лирске слике динамизују се акционим кодом, а релативизација просторних односа истиче лиминалност бића, посебно девојке, која имплицитно пољупцем од ћерке постаје драга. ${ }^{33}$

Савладавање простора изолације приказује се и као разарање једног света да би се саградио нови. Кад је град у лирици место изолације, то није епски град ${ }^{34}$ већ лирски, који гради девојчин брат, а разграђују девери, чиме се место изнова обележава међуљудским односима. У свадбеном контексту другарице питају невесту да ли брат стоји крај ње, да ли држи танку мараму и гради два града, она одговара: „И стоеше, милни дружки, и държеше, / и градеше, милни дружки, до два града; / де дойдоха, милни дружки, два деверя - / разградиха, милни дружки, до два града, / та си мене, милни дружки, заведоха“ (Иванова и Живков 2004: 326º). На персоналном плану парадигми грађење, стари, свој свет одговара невестин брат, док низу разграђивање, нови, туђи свет одговарају девери. Узимање не-

33 О свадбеној изолацији видети: Ласек 2005: 188-190.

34 У епским и лирско-епским песмама кула је типичан простор изолације: „Па утече кули у одаје, / кад на кули лијепа ђевојка, / сва се кула од ње засијала“ (Караџић 1898: $\left.562^{\circ}\right)$. 
весте аналогно је овладавању њеним домом (Иванова 1998: 12). Град је простор изолације и моделује се као затворено, ограђено, уређено место и представља микрокосмос. Девојка је пак гранична и тај несклад води разграђивању града и имплицитно преласку девојке у други свет, у мушку кућу. Како обред одмиче, невестин родитељски дом постаје знак прошлости, нови дом садашњости и будућности образујући темпоралу опозицију бивши/садашњи.

Простори изолације конструишу се и акционим кодом: „Сједи мома на високо, / на високо, на широко, / свилу преде, гајтан плете, / с гајтаном се разговара“ (Караџић 1975: 397º). С једне стране, предење и плетење манифестације су стварања нових облика, па се могу сматрати светим, а с друге посебно везани за женске иницијације и с њима у вези просторно-временску издвојеност (Карановић и Пешикан Љуштановић 1996: 5-6). ${ }^{35}$

Осим девојке, као гранично биће у изолованом простору чува се и момак: „Курво, кучко, лијепа дјевојко! / Не бијели лица, не румени, / не мами ми сина Осман-аге, / ја ћу ићи у гору зелену, / начинићу дворе јаворове, / свог ћу сина у двор затворити“ (Караџић 1975: 514º. Момак се штити од моћне, туђе девојке. ${ }^{36}$ Његовој лиминалности одговара лиминланост места изолације - у хтонском простору горе. Варијантно, девојка предлаже момковој мајци: „Ој тако ти Бога / ратарева мајко! / ако ти је жао / твог сина ратара, / а ти га загради / од села селеном, / од мене босиљком; / На воду ћу ићи, / босиљак ћу брати, / ратара љубити“ (Караџић 1975: 170). Цветно место изолације је женско, па се смештањем момка међу селен и босиљак његова граничност испољава слабљењем родне границе. Долази до родне инверзије на још једном плану. Док су град градила браћа и разграђивали девери, цвеће сади мајка, а уништава девојка. У лиминалном времену и простору, лиминална бића имају инверзне позиције: девојка је активна и руши свет узимајући драгог за себе, а момак је пасиван и угрожен. Осим што мушка изолација упућује на момкову граничност, она истиче девојачку жељу, коју девојка у краљичкој песми има моћ да оствари.

Угроженост девојке наглашена је кад се изолација моделује мотивом страже: „Тодор Тодоре претеше: / Бре ћу те украдем, Тодоро! / Не можеш море, Тодоре! / Девет су брата на врата, / десети башта на порту, / и он си држи сећиру, / кој мине да га посече. / Тодор се краде, прикраде, / младу Тодору украде, / на планину гу изведе“" (Милићевић 1884: 262). За разлику од стражара са зооморфним атрибутима

35 Загонетка стилизује мотив изолације слично лирској песми: „Изађе дика из тамника, па изнесе три златна ручника“ (Новаковић 1877: 47). Одгонетка је дуга, али дика у тамнику кореспондира с невестом која је издвојена у вајату, клету и другој соби, где припрема обредне дарове - везене пешкире.

36 У краљичкој песми с мотивом момачке изолације, опасна девојка плете на мач косе. У традицијској култури коси се приписују магијска дејства, а маркирано уређивање косе асоцира на предстојећу свадбу и гранични статус девојке (Јокић 2012: 186-187). 
(Караџић 1975: 505), у овој песми браћа са секирама губе натприродне моћи, али као чувари остају гранична бића, а границе места изолације аналогне су граници два света. Момкова лиминалност моделује се представом уљеза, туђег, странца који нарушава међе домаћег света. Одводећи девојку у онострани простор планине, његова другост приказује се и као нељудска.

Девојку, пак, може чувати и мајка: „Čuva majka Katu, / ne da je viditi / suncu ni misecu, / ni bilome danu, / ni s njom bisediti“" (Prćić 1939: IV 45). Ипак, до еротског сусрета долази у башти, где се девојка брине ко ће пазити на руже кад њу удају, чиме се најављује будућа свадба. Затворени простор, супротстављен Сунцу и Месецу, добија одлике тамног, хтонског и упућује на искуство привремене смрти кроз које лиминална бића пролазе да би се поново родила. Излазак у башту проблематизује тај свет таме и управо у башти, на светлости дана, најављује се нови живот - момковим присуством и девојчином најавом свадбе на јесен.

Када девојка, попут виле која зида град, гради кулу: „Failila se Mara, / da ć' sazidat Mara, / pod Somborom kulu. / Troja ć vrata Mara od suvoga zlata / i devet pendžera od dragog kamena. / U pendžer je Mara / ružu usadila“ (Prćić 1939: IV 46º), формира се женски простор, али то није типичан простор изолације. Он је пропустљив за момка: „Naišo je Stipe / na vrancu konjicu, / pa govori Stipe: / Pusti ružo vrižu / da uđem u kulu, / pa da vidim, ružo, / šta mi Mara radi, / jel' mi Mara spava, / jel' o meni sanja“. ${ }^{37}$ Док је изолација у претходној песми била обележена тамом, овде је кула простор светлости - златних врата и прозора украшених драгим камењем. ${ }^{38}$ Девојчина граничност истакнута је улогом зидарице и сценом сна као стања између живота и смрти. Кула јесте лиминална, али је пре место сусрета него изолације. Ружа фитонимним кодом такође упућује на граничност. Она је, као трновита, знак границе између овог и оног света, пошто расте у дивљем простору шуме, али и уз ограде, и у баштама, она заузима граничну позиције према простору, туђем и свом (Карановић 2010: 161-162). Иако је у претходној песми ружа расла у башти, чувала је лиминалну симболику јер се повезивала с мотивом свадбе. Овде та симболика јача јер цвет расте на међи простора где је девојка затворена (на прозору). Врежом се тај простор затвара, али и отвара помажући момку да савлада препреку. Тиме се потврђује амбивалентност биљке, границе и девојке као граничног бића.

Кад се прате промене девојака и момака током граничних животних ситуација у усменим лирским песмама, уочава се сва сложе-

37 О изолацији током краљичког обреда видети: Јокић 2012: 177-178.

38 У „Женидби Максима Црнојевића“, Милош Војиновић добија дарове, међу којима је: „у челенци алем камен драги, / који сјаје како јарко сунце“ и златну кошуљу на којој је извезена змија „на глави јој алем камен драги, / каде иде момак са ђевојком / у ложницу, да не носи св’јеће, / нек свијетли алем камен драги“ (Караџић 1988а: 89º). 
ност и нијансираност граничних идентитета, као и њихова привременост. Превазилазећи границе свог тела, удвајајући се, маскирајући се, сусрећући се с Другим и другачијим, лирски јунаци и јунакиње моделују се као гранична бића. Истовремено, у ограниченом времену обреда и у граничним просторима, у привременом инверзном поретку света, песме пружају утопијски потенцијал алтернативне стварности. Таква стварност обележена је, као и сама граничност момака и девојака, оказионалношћу.

\section{ИЗВОРИ}

Арнаудов, Михаили Христо Вакарелски. Българско народно творчество в дванадесет тома. T. V. Обредни песни. Варна: LiterNet, 2004.

Беновска-Събкова, Милена. Любовни песни. Българска народна поезия и проза в седем тома, том 5, ред. Тодор Моллов. Варна: LiterNet, 2005.

Бован, Владимир. Срйске народне умойворине са Косова и Мейохије на ситраницама „Цариіраяскої іласника”, Лепосавић: Дом културе „Свети Сава“, 1996.

Бошковић, Стеван. Бачванске иесме. Нови Сад: Српска народна задружна штампарија, 1879.

Бушетић, Тодор. „Српске народне песме с мелодијама из Левча“. Срйски ейноірабски зборник, 3 (1902).

Веселиновић, Јован. „Лазарице. Српски народни обичај (у Врању и врањском округу)“. Брасйво 4 (1890): 66-94.

Геземан, Герхард. 1925. Ерланіенски рукойис. Сремски Карловци: Српска краљевска академија. Доступно на: http://www.erl. monumentaserbica.com/spisak.php

Ђорђевић, Тихомир. 1907. „Српске народне игре“. Срйски ейноіраббски зборник 1 (1907): 1-159.

Иванова, Радости Тодор Живков. Българска народна поезия и проза в седем тома. T. II. Обредни песни. Варна: LiterNet, 2004.

Карановић, Зоја. Нароgне иесме у Даници. Нови Сад: Матица српска; Београд: Институт за књижевност и уметност, 1990.

Караџић, Вук Стефановић. Срӣске нароgне ӥјесме V. Београд: Штампарија Краљевине Србије, 1898.

Караџић, Вук Стефановић. Срйске нароgне йјесме II. Београд: Просвета, 1988a.

Караџић, Вук Стефановић. Срйске нароgне ӥјесме III. Београд: Просвета, 19886.

Караџић, Вук Стефановић. Срӣске народне ӥјесме из необјављених рукой са I. Београд: САНУ. Одељење језика и књижевности, 1973.

Караџић, Вук Стефановић. Срйске нарояне ӥјесме из необјавъених рукоüuca V. Београд: САНУ, Одељење језика и књижевности, 1974. 
Караџић, Вук Стефановић. Срйске нароgне йјесме I. Београд: Просвета, 1975.

Матицки, Миодраг. Нароgне йесме у Вили. Нови Сад: Матица српска; Београд: Институт за књижевност и уметност, 1985.

Милићевић, Милан Ђ. Краљевина Србија. Београд: Краљевска српска државна штампарија, 1884.

Мокрањац, Стеван. Зайиси нароgних мелоgија. Београд: Научно дело, 1966.

Николић, Владимир. „Из Лужице и Нишаве“. Срйски ейноірафбски зборник 16 (1910): 1-503.

Николић, Григорије. Срйске нароgне иесме І. Нови Сад: Српска књижара и штампарија Браће М. Поповића, 1888.

Новаковић, Стојан. Срйске нарояне заі̄онейке, Београд и Панчево: Књижарница В. Валожића, Књижарница Браће Јовановић, 1877.

Петрановић, Богољуб. Срйске нарояне йјесме из Босне и Хериейовине I. Сарајево: Свјетлост,1989.

Поповић, Павао. „Краљице. Српски народни обичај о Тројчину дне“. Брастиво 2 (1888): 7-29.

Радојевић, Вељко. „Српске народне пјесме из околине херцегновске“. Брастиво 5 (1892): 226-294.

Рајковић, Ђорђе. 1869. Срйске нароgне иеесме (женске), Нови Сад: Штампарија Игњата Фукса.

Раденковић, Љубинко. Нароgне басме и бајања. Ниш: Градина; Приштина: Јединство; Крагујевац: Светлост, 1982.

Чајкановић, Веселин. Срйске нароgне йрийовейке. Београд: Српска краљевска академија, 1927.

Ястребов, И.С. 1886. Объчаи и пюсни туреикихъ Сербовъ. С. Петербург: Типографіа В. С. Балашева.

Andrić, N. (ur.). 1929. Hrvatske narodne pjesme VII. Zagreb: Matica hrvatska.

Bosanac, S. (ur.). 1897. Hrvatske narodne pjesme I/2. Junačke pjesme. Zagreb: Matica hrvatska.

Kuhač, F. 1941. Južno-slovjenske narodne popievke V. Zagreb: Jugoslavenska akademija znanosti i umjetnosti.

Lovretić, Josip. 1897. „Otok. Narodni život i običaji“. Zbornik za narodni život i običaje Južnih Slavena II. Zagreb: JAZU.

Prćić, Ive. Bunjevačke narodne pisme. Subotica: Osvit, 1939.

Žganec, Viktor. Hrvatske narodne pjesme kajkavske. Zagreb: Matica hrvatska, 1950.

\section{ЛИТЕРАТУРА}

Бенвенист, Емил. Речник индоевойских усйанова, прев. А. Лома. Срем- 
ски Карловци/Нови Сад: Издавачка књижарница Зорана Стојановића, 2002.

Генеп, Арнолд ван. Обреgu йрелаза. Београд: СКЗ, 2005.

Гура А. В. „Венок свадбеный“. Славянские древности. Этнолингвистический словарь, том 1. Ред. И. Н. Толстой. Москва: Международные отношения, 1995. 321-325

Детелић, Мирјана. Мийски йросӣор и ейика. Београд: САНУ, АИЗ „Досије“, 1992.

Диздаревић Крњевић, Хатиџа. Уӣва злайокрила. Београд: Филип Вишњић, 1997.

Зайковские, Виталий и Татяна. „Ритуальное обнажение тела в сказках о приметах царевны“. Коgови словенских кулитура 4 (1999): 111-130.

Иванова, Радост. Свадба као систем знакова, прев. Д. Ајдачић. Коgови словенских куличура 3 (1998): 7-13.

Јокић, Јасмина. Краличке иесме. Рийуал и йоезија. Београд: Друштво за српски језик и књижевност Србије, 2012.

Карановић, Зоја и Љиљана Пешикан Љуштановић. „Трагови представа о митско-религијским аспектима ткања и предења у српској усменој традицији“. Кюижевна истиорија 28.98 (1996): 5-15.

Карановић, Зоја. „Архајски корени српске усмене лирске поезије“. У Анйолоїча срйске лирске усмене йоезије. Нови Сад: Светови, 1996. 251-309.

Карановић, Зоја и Јасмина Јокић. Смеховно и еройско у срйској нароgној кулйири и йоезији. Нови Сад: Филозофски факултет, 2009.

Карановић, Зоја. Небеска невести а. Београд: Друштво за српски језик и књижевност Србије, 2010.

Караџић, Вук Стефановић. Срйски ријечник. Беч: Штампарија Јерменског манастира, 1852.

Ласек, Агњешка. „Медијаторске границе у свадбеним песмама Јужних Словена“. Зборник Матиице срйске за книжевности и језик LIII. 1-3 (2005): 179-252.

Левингтон, Г. А. „Нека општа питања изучавања свадбеног обреда“, прев. Р. Мечанин. Расковник 9. 31 (1982): 95-102.

Лома, Александар. „’Женидба с препрекама' и ратничка иницијација“. Кояови словенских кулитура 3 (1998): 196-217.

Лома, Александар. Пракосово. Београд: Балканолошки институт САНУ, 2002.

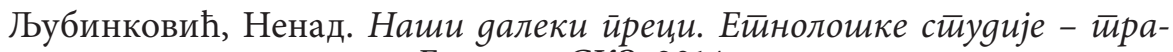
іань и йромишльюь а Београд: СКЗ, 2014.

Мајерхоф, Барбара. „Обреди прелаза: процес и парадокс“, прев. Н. Петровић. Граяина 10 (1986): 18-39.

Марјановић, Весна. Маске, маскираюе и ритиуали у Србији. Београд: Чигоја штампа, Етнографски музеј, 2008.

Медаковић, В. М. Г. Животи и обичаи Црног̄орац̧а. Нови Сад: Брзотиск Епископске кньигопечатнь, 1860. 
Опачић-Ћаница, Станко. „Народни обичаји Срба на Кордуну. Свадбени обичаји“. Расковник 10. 37 (1983): 3-22.

Пантелић, Никола. „Свадбени обичаји у Јадру“. Гласник Ейноі̄рафскоі музеја 30 (1968): 113-127.

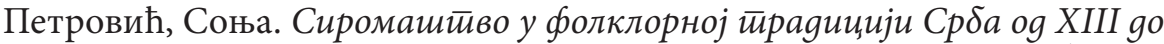
ХІХ века. Прилоі̄ йроучаваюу нарояне кулйуре, Београд: Албатрос плус, 2014.

Попов, Миливој. „Свадба у северном Банату“. Pag војвођанских музеја 18-19 (1969/1970): 29-72.

Раденковић, Љубинко. „Бројеви у народној магији“. Расковник 19.71-72 (1993): 87-95.

Раденковић, Љубинко. Нарояна бајана коg Јужних Словена. Ниш: Просвета; Београд: Балканолошки институт САНУ, 1996.

Сикимић, Биљана. „Невестинска имена: од хипокористика до пејоратива“. Срйски језик 1-2 (1998): 29-55.

Сикимић, Биљана. „Кожа деверска“. Срйски језик 4 (1999): 337-360.

Тарнер, Виктор. „Варијације не тему лиминалности“, прев. Б. Мишић и В. Костов. Граяина 10 (1986): 40-57.

Топорков, А. Л. „Стол“. Славянские древности. Этнолингвистический словарь, том 1. Ред. И. Н. Толстой. Москва: Международные отношения, 2012. 165-170

Чајкановић, Веселин. Сӣуguје из релиіије и болклора 1910-1924. Београд: СКЗ, БИГЗ, Просвета, Партенон, 1994.

Шневајс, Едмунд. „Апотропејски елементи у свадбеним обичајима код Срба и Хрвата“. Гласник Ейноі̄рафскої музеја 2 (1927): 21-27.

Antonijević, Dragana. „Antropološko poimanje bajke kao optimističkog žanra“. Antropologija 13. 1 (2013): 9-22.

Čale Feldman, Lada. Euridikini osvrti. Zagreb: Naklada MD, Centar za ženske studije, 2001.

Bahtin, Mihail. Stvaralaštvo Fransoa Rablea i narodna kultura srednjeg veka i renesanse, prev. I, Šop i T. Vučković. Beograd: Nolit, 1978.

Bandić, Dušan. Tabu u tradicionalnoj kulturi Srba. Beograd: Biblioteka XX vek, 1980.

Belaj, Vitomir. Hod kroz godinu. Mitska pozadina hrvatskih narodnih običaja i vjerovanja. Zagreb: Golden marketing, 1998.

Bilefeld, Ulrih. Stranci: prijatelji ili neprijatelji, prev. D. Gojković. Beograd: Biblioteka XX vek, 1998.

Bratić, Dobrila. Gluvo doba. Beograd: Biblioteka XX vek, 1993.

Chausidis, Nikos. „The magic and aesthetic function of mythical images in the South Slav traditional culture". The magical and aesthetic in the folklore of Balkan Slavs. Ed. Dejan Ajdačić. 1994, 5-20.

Foucault, Michel. 1997. Of Other Spaces: Utopias and Heterotopias.

<http://www.vizkult.org/propositions/alinein nature/pdfs/FoucaultOfOtherSpaces1967.pdf $>11.6 .2019$.

Gunnell, Terry, ed. Masks and Mumming in the Nordic Area. Introduction. 
Uppsala: Kungl. Gustav Adolfs Akademien för svensk folkkultur, 2007, 27-43.

Hamilton, Malkolm. Sociologija religije, prev. Đ. Trajković. Beograd: Clio, 2003.

Ivanova, Radost. Traditional Bulgarian Wedding, trans. N. Panova. Sofia: Svyat Publishers, 1987.

Jaspers, Karl. Filozofija egzistencije. Uvod u filozofiju, prev. I. Ivanji. Beograd: Prosveta, 1973.

Kasirer, Ernst. Filozofija simboličkih oblika II, prev. O. Kostrešević. Novi Sad: Dnevnik, Književna zajednica Novog Sada, 1985.

Levinas, Emanuel. Vrijeme i drugi, prev. S. Đuzulan. Podgorica: Oktoih, 1997.

Lič, Edmund. Kultura i komunikacija, prev. B. Hlebec. Beograd: Biblioteka XX vek, 1983.

Mencej, Mirjam. Pomen vode v predstavah starih Slovanov o posmrtnem življenju in šegah ob smrti. Ljubljana: Slovensko etnološko društvo, 1997.

Nenola, Aili.1999. "Gender, Culture and Folklore".

$<$ http://sapientia.ualg.pt/bitstream/10400.1/1365/1/1Ninola.PDF>11.6.2019.

Radulović, Lidija. Pol/rod i religija. Beograd: Srpski genealoški centar, Odeljenje za antropologiju i etnologiju Filozofskog fakulteta, 2009.

Turner, Victor. The Ritual Process. Structure and Anti-Structure. New Brunswick, London: Aldine Transaction, 2008.

Valdenfels, Bernhard. Topografija stranog, prev. D. Prole. Novi Sad: Stilos, 2005.

Valdenfels, Bernhard. Osnovni motivi fenomenologije stranog, prev. D. Prole. Novi Sad, Sremski Karlovci: Izdavačka knjižarnica Zorana Stojanovića, 2010.

Ana Vukmanović

The Liminal Beings of Oral Lyric

- on Crossing of Spatial and Existential Boundaries of Lyrical Heroines and Heroes

\section{Summary}

The paper discusses the complex position of lyric heroines and heroes as liminal beings in limited situations. They are observed as the figures of the Other and the alien. Since the oral lyric comprises both the "female" and "male" text, the radical Other cannot be identified with the woman, even if female otherness is more emphasized in a patriarchal community. The songs tell of the maidens and youths who meet their bodily boundaries in rituals, as part of the motif of doubling or looking at their reflections on the water surface. The new identity is contested in contact with the Other. This is the case with the maiden who comes from afar, crossing 
the boundaries, leaving her family home, ceasing to be a daughter and a sister, and becomes a bride - a wife. Masks mark the liminal identity of youths and maidens. Wearing the masks, they gain zoomorphic characteristics (wolf hats, other zoomorphic attributes), or their gender identity is relativized. When maidens get dressed as lads or take some of the heroic attributes (most often the saber), they are marked as powerful, they enter the male social sphere or meet a beloved youth. The inversion of the dominant order during the ritual creates the space of freedom, which provides a utopian potential of an alternate reality. This kind of reality is possible during the restricted time and space, marked by occasionality, in a similar manner as the liminality of maidens and youths is occasional. Both the nature of liminal beings and the relationship of the community therewith is marked by ambiguity. The maidens in the queen's ritual are at the same time unknown (different from who they are in profane times) and their plain old village maiden selves. The unknown lad is alien, strange, but desirable as well. They are both dangerous and in danger, and accordingly, the taboos that refer to them (the prohibition of speech, looking back, revealing the face/identity, isolation, etc.) aim not only to protect endangered beings from evil eyes and spirits but to protect the community from mighty liminal beings. The oral lyric songs accompany people during the limit-situations and serve to show the complexity of liminal identities.

Keywords: oral lyric, liminal being, alien, the other, identity, mask, taboo

Примљен: 7. 9. 2019.

Прихваћен: 1.6.2020. 